UDC 53.072; 53:681.3

\author{
${ }^{2}$ T.A. Shmygaleva*, ${ }^{2}$ Sh.E. Jeleunova, ${ }^{2}$ A.A. Kupchishin, ${ }^{1,3}$ A.I. Kupchishin, ${ }^{2}$ E.V.Smygalev \\ ${ }^{1}$ Institute of New Chemical Technologies and Materials, Kazakhstan, Almaty \\ ${ }^{2}$ al-Farabi Kazakh National University, Kazakhstan, Almaty \\ ${ }^{3}$ Abai Kazakh National Pedagogical University Kazakhstan, Almaty \\ *E-mail: Shmyg1953@mail.ru
}

\title{
Generation of radiating defects in the copper irradiated by ions of aluminum
}

\begin{abstract}
Processes of radiation formation of defects in the copper irradiated by ions of aluminum are considered in the work. Algorithms of calculation of concentration of radiating defects are developed, presented in the form of block diagrams. The regularities of behavior of concentration of cascade areas in the copper irradiated by aluminum are revealed. Results of calculations are presented in the form of charts and tables.

Key words: electrogenerators, copper, contact wires, radiators, bearings, aluminum.
\end{abstract}

Т.А. Шмыгалева. Ш.Е. Желеунова, А.А. Купчишин, А.И. Купчишин, Е.В. Шмыгалев, Алюминий иондарымен сәулелендірілген мыстағы радиациялық дефект генерациясы

Бұл жұмыста алюминий иондарымен сәулендірілген мыстың радияциялық дефект түзілу үдерістері қарастырылған. Радиациялық дефектілердің концентрацияларының есептеу алгоритмдері жасалып, блок-сызбанұсқа түрінде келтірілген. Алюминиймен сәулелендірілген мыстың каскадты аймақтарының концентрацияларының өзгеру зандылықтары анықталған. Есептеу нәтижелері график және кесте түрінде келтірілген.

Түйін сөздер: электрогенераторлар, мыс, контакт сымы, радиаторлар, алюминий.

\section{Ш.Е. Желеунова, А.А. Купчишин, А.И. Купчишин, Е.В. Шмыгалев, Т.А. Шмыгалева}

Генерация радиационных дефектов в меди, облученной ионами алюминия

В работе рассматриваются процессы радиационного дефектообразования в меди, облученной ионами алюминия. Разработаны алгоритмы расчета концентрации радиационных дефектов, представлены в виде блок-схем. Выявлены закономерности поведения концентрации каскадных областей в меди, облученной алюминием. Результаты расчетов представлены в виде графиков и таблиц.

Ключевые слова: электрогенераторы, медь, контактная проволока, радиаторы, алюминий.

\section{Introduction}

Copper, its connections and flotages find wide application in various industries. Copper in the electro technology is used in the pure state: in manufacture of cable products, trunks of naked and contact wires, electrogenerators, the telephone and cable equipment and radio equipment. Heat-exchangers, vacuum-devices, pipelines are made from copper. More than $30 \%$ of copper spent on flotages. Flotages of copper with other metals are used in mechanical engineering, in the automobile and tractor industry (radiators, bearings), for manufacturing the chemical equipment. High viscosity and plasticity of metal allow to apply copper to manufacturing varied products with very complex pattern. The wire from red copper in burned condition becomes so soft and plastic, that from it without effort it is possible to twist every possible cord and to curve the most complex elements of an ornament.

Flotages on the basis of copper are considered in work, as now bunches of ions are intensively applied in mechanical engineering at reception of ultra strong details and materials. For hardening units, details and materials in mechanical engineering we develop a new in cascade - probabilistic method $(\mathrm{CPM})$, in which is based on reception of analytical expressions and further use of cascade - probabilis- 
tic functions (CPF). CPF make sense probabilities that the particle generated on some depth $h^{\prime}$ will reach depth $h$ after $\mathrm{n}$-th of impacts.

\section{Experiment}

For calculation CPF the formula (159) [1] is used. The parameters of approximation entering in approximation expression, the approximating section of interoperability calculated under the Rutherford formula have been found. The regularities of selection approximation coefficient, regularities of behavior of actual area of result are found at calculation of cascade - probabilistic functions depending on number of interactions and depth of penetration of particles at various values of initial energy.

With use of the received expression for CPF concentration vacant clusters under the formula (176 [1] is calculated. The algorithm of calculation is presented in figures 1,2. Results of calculations are resulted in tables 1, 2 and in figures 3-5.

For easy flying particles and easy targets curves increase, peaking, then decrease up to zero. With an increase of initial energy of a particle curves are displaced to the right. With an increase of threshold en- ergy of the $E_{c}$ of value of concentration decrease, and curves pass significantly below, transition through a maximum is carried out more smoothly. At energy $\mathrm{E}_{0}=100 \mathrm{keV}$ the curve decreases. With an increase of nuclear weight of a flying particle value of function in a point of a maximum increases and, consequently, curves pass above while values of depths decrease. With an increase of nuclear number of a target for the same flying particles value of function in a point of a maximum slightly increases, values of depths decrease.

\section{Results and Discussion}

The finding of area of result of concentration of radiating defects at an irradiation of copper ions of aluminum has allowed to reveal following regularities:

1. With reduction of initial energy of a primary particle the interval of area of result is displaced to the right, values of concentration of radiating defects increase

2. Depending on depth of penetration initial and final values of number of interactions increase, the interval of area of result (n0 n1) also increases and displaced to the right 


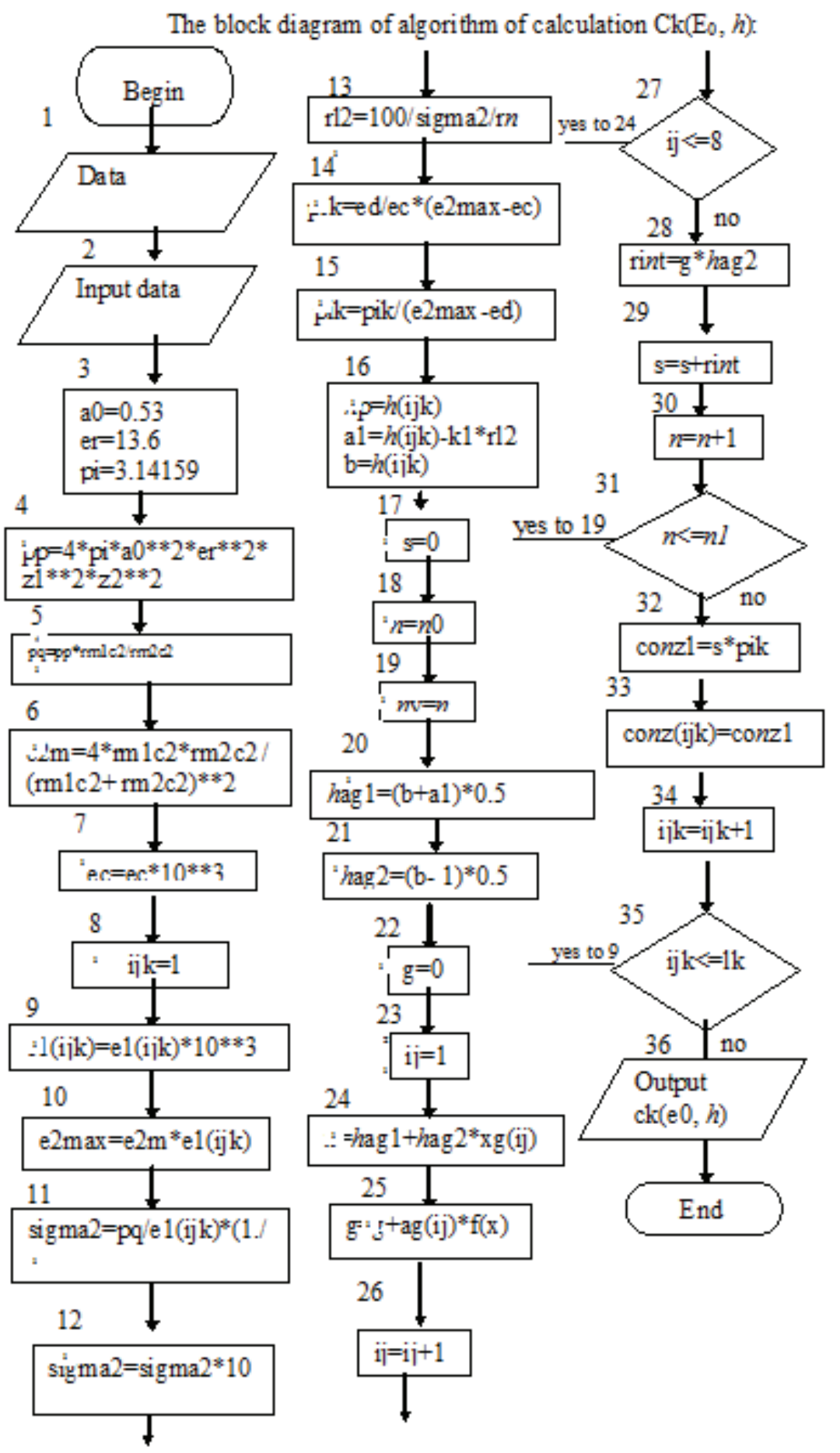

Figure 1 - The block diagram of algorithm of calculation $\mathrm{Ck}\left(\mathrm{E}_{0}, h\right)$ The block diagram of calculation of subintegral function $\mathrm{f}(h 1)$ 


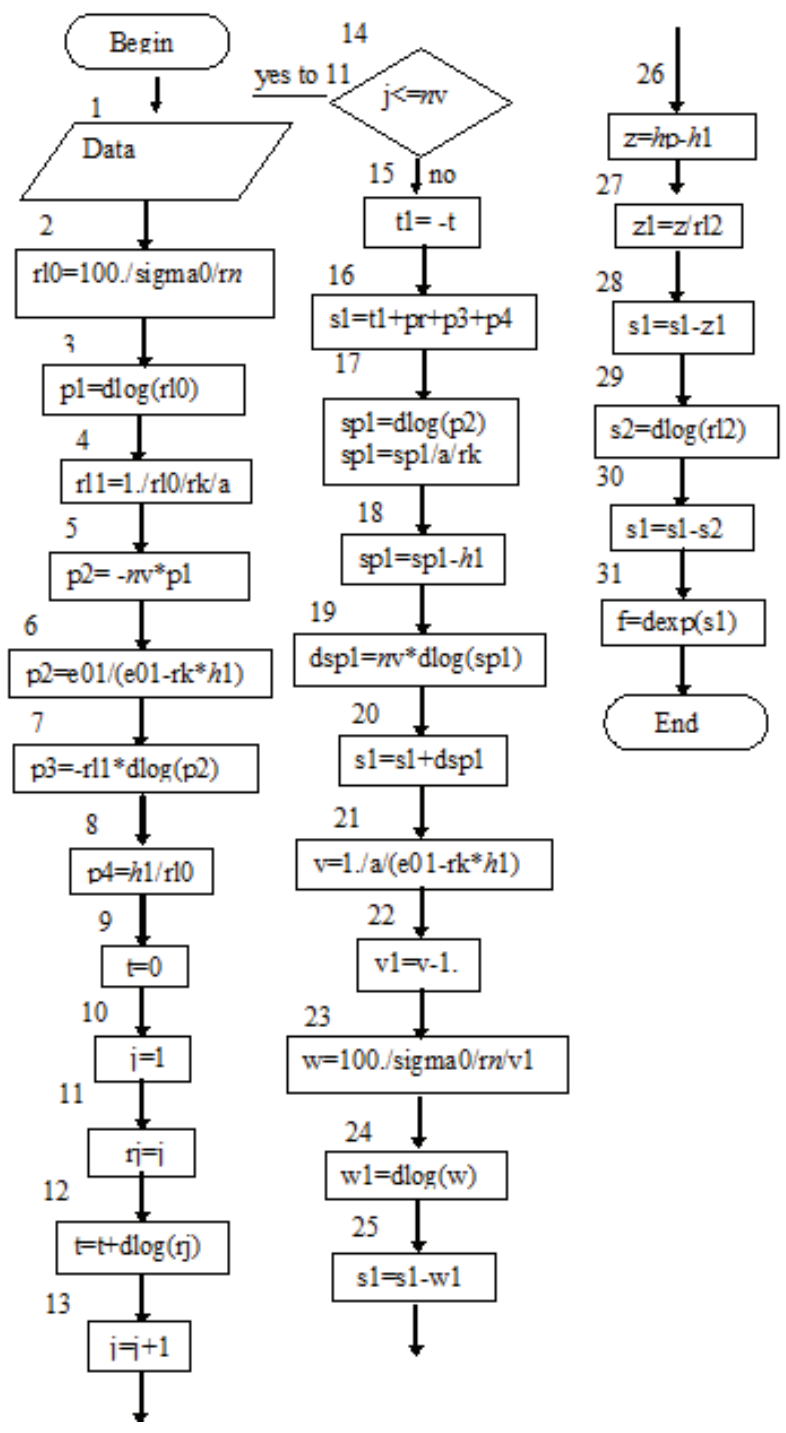

Figure 2 - The block diagram of calculation of subintegral function $\mathrm{f}(h 1)$

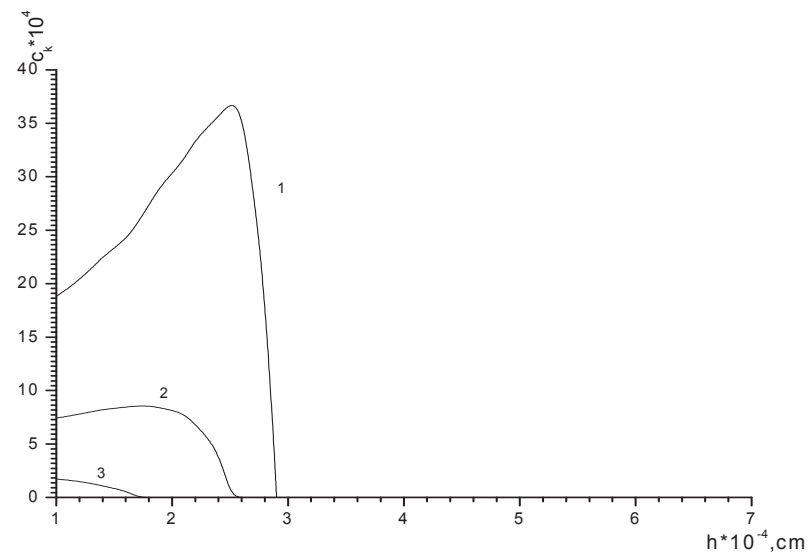

Figure 3 - Dependence of concentration of cascade areas on depth at an irradiation of copper ions of aluminium: $\mathrm{E}_{0}=1000$ кэВ, $\mathrm{E}_{\mathrm{c}}=50$ (1), 100 (2), 200 (3) эВ 


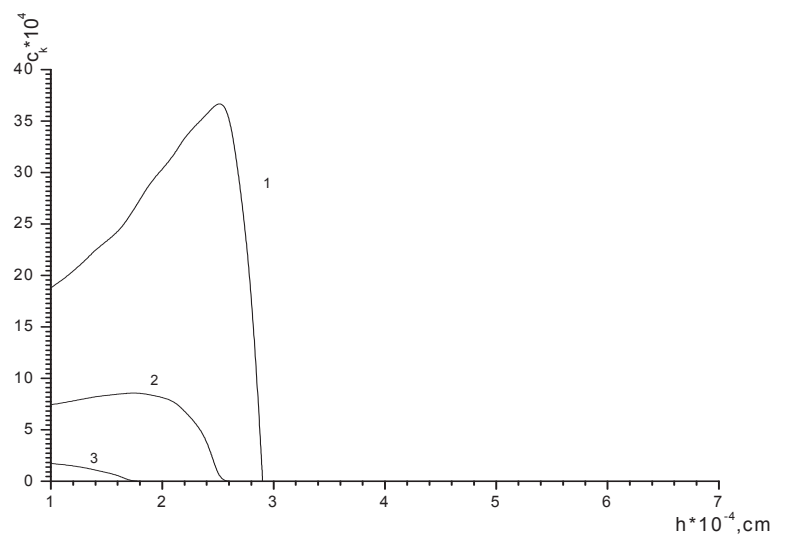

Figure 4 - Dependence of concentration of cascade areas on depth at an irradiation of copper ions of aluminum: $\mathrm{E}_{0}=500$ кэВ, $\mathrm{E}_{\mathrm{c}}=50(1), 100(2), 200$ (3) эВ

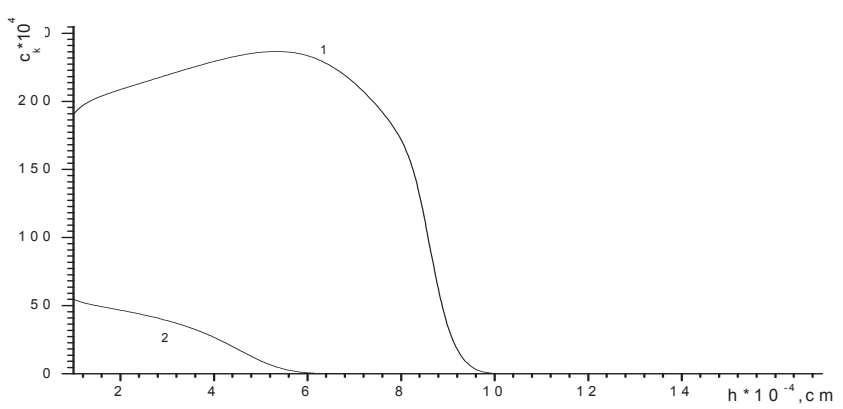

Figure 5 - Dependence of concentration of cascade areas on depth at an irradiation of copper ions of aluminum:

$$
\mathrm{E}_{0}=200 \text { кэВ, } \mathrm{E}_{\mathrm{c}}=50(1), 100 \text { (2) эВ }
$$

Table 1 - Borders of a range of definition of concentration of radiating defects for aluminum in copper at $\mathrm{E}_{\mathrm{c}}=50,100,200$ кэB, $\mathrm{E}_{0}=800$ кэВ

\begin{tabular}{|c|c|c|c|c|}
\hline $\mathrm{h} * 10^{4}, \mathrm{~cm}$ & $\mathrm{C}_{\mathrm{K}}$ & $\mathrm{E}_{0}$, кэВ & $\mathrm{n}_{0}$ & $\mathrm{n}_{1}$ \\
\hline \multirow[t]{3}{*}{0} & 4469 & \multirow[t]{3}{*}{800} & \multirow[t]{3}{*}{1} & \multirow[t]{3}{*}{31} \\
\hline & 2054 & & & \\
\hline & 846 & & & \\
\hline \multirow[t]{3}{*}{0,6} & 5460 & \multirow[t]{3}{*}{700} & \multirow[t]{3}{*}{502} & \multirow[t]{3}{*}{856} \\
\hline & 2475 & & & \\
\hline & 982 & & & \\
\hline \multirow[t]{3}{*}{1,2} & 6786 & \multirow[t]{3}{*}{600} & \multirow[t]{3}{*}{1316} & \multirow[t]{3}{*}{1879} \\
\hline & 3018 & & & \\
\hline & 1133 & & & \\
\hline \multirow[t]{3}{*}{1,8} & 8607 & \multirow[t]{3}{*}{500} & \multirow[t]{3}{*}{2436} & \multirow[t]{3}{*}{3159} \\
\hline & 3719 & & & \\
\hline & 1275 & & & \\
\hline \multirow[t]{3}{*}{2,5} & 11249 & \multirow[t]{3}{*}{400} & \multirow[t]{3}{*}{4006} & \multirow[t]{3}{*}{4912} \\
\hline & 4637 & & & \\
\hline & 1331 & & & \\
\hline \multirow[t]{3}{*}{2,8} & 13011 & \multirow[t]{3}{*}{350} & \multirow[t]{3}{*}{5005} & \multirow[t]{3}{*}{6028} \\
\hline & 5166 & & & \\
\hline & 1244 & & & \\
\hline \multirow[t]{3}{*}{3,1} & 15292 & \multirow[t]{3}{*}{300} & \multirow[t]{3}{*}{6255} & \multirow[t]{3}{*}{743} \\
\hline & 5745 & & & \\
\hline & 971 & & & \\
\hline
\end{tabular}


Table 1

\begin{tabular}{|c|c|c|c|c|}
\hline \multirow[t]{3}{*}{3,2} & 16350 & \multirow[t]{3}{*}{280} & \multirow[t]{3}{*}{6818} & \multirow[t]{3}{*}{8030} \\
\hline & 5957 & & & \\
\hline & 761 & & & \\
\hline \multirow{3}{*}{3,4} & 17643 & \multirow[t]{3}{*}{260} & \multirow[t]{3}{*}{7502} & \multirow[t]{3}{*}{8747} \\
\hline & 6189 & & & \\
\hline & 463 & & & \\
\hline \multirow[t]{3}{*}{3,5} & 18947 & \multirow[t]{3}{*}{240} & \multirow[t]{3}{*}{8200} & \multirow[t]{3}{*}{9498} \\
\hline & 6333 & & & \\
\hline & 26 & & & \\
\hline \multirow[t]{3}{*}{3,6} & 20387 & \multirow[t]{3}{*}{220} & \multirow[t]{3}{*}{8947} & \multirow[t]{3}{*}{10328} \\
\hline & 6393 & & & \\
\hline & 0 & & & \\
\hline \multirow[t]{3}{*}{3,7} & 21969 & \multirow[t]{3}{*}{200} & \multirow[t]{3}{*}{9803} & \multirow[t]{3}{*}{11264} \\
\hline & 6305 & & & \\
\hline & 0 & & & \\
\hline \multirow[t]{3}{*}{3,8} & 23914 & \multirow[t]{3}{*}{180} & \multirow[t]{3}{*}{10838} & \multirow[t]{3}{*}{12346} \\
\hline & 6016 & & & \\
\hline & 0 & & & \\
\hline \multirow[t]{3}{*}{4} & 25747 & \multirow[t]{3}{*}{160} & \multirow[t]{3}{*}{11944} & 13533 \\
\hline & 5202 & & & \\
\hline & 0 & & & \\
\hline 4,2 & 27524 & 140 & 13229 & 14829 \\
\hline & 3517 & & & \\
\hline & 0 & & & \\
\hline 4,3 & 28849 & 120 & 14749 & 16466 \\
\hline & 122 & & & \\
\hline & 0 & & & \\
\hline 4,4 & 28608 & 100 & 16592 & 18460 \\
\hline & 0 & & & \\
\hline & 0 & & & \\
\hline 4,5 & 22883 & 80 & 18752 & 20676 \\
\hline & 0 & & & \\
\hline & 0 & & & \\
\hline 4,6 & 15279 & 70 & 20054 & 22070 \\
\hline & 0 & & & \\
\hline & 0 & & & \\
\hline 4,7 & 526 & 60 & 21575 & 23713 \\
\hline & 0 & & & \\
\hline & 0 & & & \\
\hline
\end{tabular}


Table 2 - Borders of a range of definition of concentration of radiating defects for aluminum in copper at $\mathrm{E}_{\mathrm{c}}=50,100,200$ кэВ, $\mathrm{E}_{0}=200$ кэВ

\begin{tabular}{|c|c|c|c|c|}
\hline $\mathrm{h} * 10^{4}, \mathrm{~cm}$ & $\mathrm{C}_{\mathrm{K}}$ & $\mathrm{E}_{0}$, кэВ & $\mathrm{n}_{0}$ & $\mathrm{n}_{1}$ \\
\hline \multirow[t]{3}{*}{0} & 19051 & \multirow[t]{3}{*}{200} & \multirow[t]{3}{*}{7} & \multirow[t]{3}{*}{109} \\
\hline & 5468 & & & \\
\hline & 0 & & & \\
\hline \multirow[t]{3}{*}{0,13} & 20165 & \multirow[t]{3}{*}{180} & \multirow[t]{3}{*}{614} & \multirow[t]{3}{*}{1013} \\
\hline & 5073 & & & \\
\hline & 0 & & & \\
\hline \multirow[t]{3}{*}{0,26} & 21486 & \multirow[t]{3}{*}{160} & \multirow[t]{3}{*}{1464} & \multirow[t]{3}{*}{2049} \\
\hline & 4341 & & & \\
\hline & 0 & & & \\
\hline \multirow[t]{3}{*}{0,4} & 23011 & \multirow[t]{3}{*}{140} & \multirow[t]{3}{*}{2556} & \multirow[t]{3}{*}{3327} \\
\hline & 2940 & & & \\
\hline & 0 & & & \\
\hline \multirow[t]{3}{*}{0,53} & 23929 & \multirow[t]{3}{*}{120} & \multirow[t]{3}{*}{3775} & \multirow[t]{3}{*}{4665} \\
\hline & 101 & & & \\
\hline & 0 & & & \\
\hline \multirow[t]{3}{*}{0,65} & 23168 & \multirow[t]{3}{*}{100} & \multirow[t]{3}{*}{5136} & \multirow[t]{3}{*}{6182} \\
\hline & 0 & & & \\
\hline & 0 & & & \\
\hline \multirow[t]{3}{*}{0,78} & 18776 & \multirow[t]{3}{*}{80} & \multirow[t]{3}{*}{6996} & \multirow[t]{3}{*}{8189} \\
\hline & 0 & & & \\
\hline & 0 & & & \\
\hline \multirow[t]{3}{*}{0,84} & 14783 & \multirow[t]{3}{*}{70} & \multirow[t]{3}{*}{9275} & \multirow[t]{3}{*}{10664} \\
\hline & 0 & & & \\
\hline & 0 & & & \\
\hline \multirow[t]{3}{*}{0,9} & 525 & 60 & 10752 & 12257 \\
\hline & 0 & & & \\
\hline & 0 & & & \\
\hline
\end{tabular}

\section{Conclusion}

Thus, in this paper the algorithms for calculating the concentration of radiation-induced defects have been obtained and presented in the form of block diagrams. The calculations of concentration of ra- diation defects in copper irradiated with aluminum ions were given. It were found the regularities of the behavior of the domain of definition, depending on the initial energy of the primary particle, the depth of penetration of the threshold energy.

\section{References}

1. Kupchishin A.A., Kupchishin A.I., Shmygaleva T.A., etc. Modelling on the PC and experimental researches of radiating processes in iron and firm flotages. The monography. Almaty. - 2010 - p. 263. 